\%

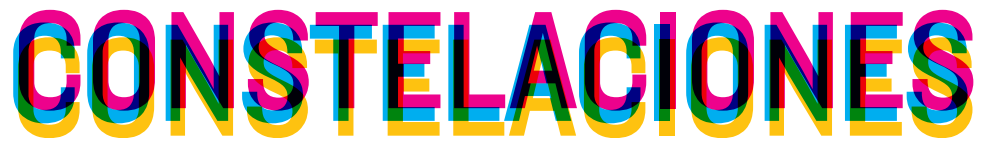

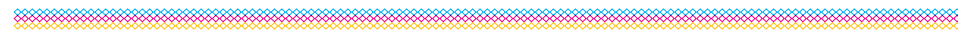


CONSTELACIONES n², mayo 2014

Revista de Arquitectura de la Universidad CEU San Pablo

Architecture Magazine of CEU San Pablo University

Periodicidad anual

Annual periodicity

COMITÉ DE REDACCIÓN EDITORIAL COMMITTEE

\section{Director Director}

Juan García Millán

Jefa de Redacción Editor in Chief

Covadonga Lorenzo Cueva

Secretario de Redacción Editorial Clerk

Rodrigo Núñez Carrasco

Maquetación y producción Design and production

María Fernández Hernández

Vocales Board Members

Fernando del Ama Gonzalo. Escuela Politécnica Superior, Universidad CEU San Pablo, Madrid

Pablo Campos Calvo-Sotelo. Escuela Politécnica Superior, Universidad CEU San Pablo, Madrid

Alfonso Díaz Segura Escuela Superior de Enseñanzas Técnicas, Universidad CEU Cardenal Herrera, Valencia

Mayka García Hípola. Escuela Politécnica Superior, Universidad CEU San Pablo, Madrid

Sonia Izquierdo Esteban. Escuela Politécnica Superior, Universidad CEU San Pablo, Madrid

Javier Sáenz Guerra. Escuela Politécnica Superior, Universidad CEU San Pablo, Madrid

\section{CONSEJO EDITORIAL EDITORIAL BOARD}

Beatriz Colomina. School of Architecture, Princeton University, New Jersey

Carmen Díez Medina. Escuela de Ingeniería y Arquitectura, Universidad de Zaragoza

María Antonia Frías Sargadoy. Escuela Técnica Superior de Arquitectura, Universidad de Navarra

Ángel González García. Facultad de Geografía e Historia, Universidad Complutense de Madrid

Juan Miguel Hernández Léon. Escuela Técnica Superior de Arquitectura, Universidad Politécnica de Madrid

Juan José Lahuerta Alsina. Escuela Técnica Superior de Arquitectura, Universidad Politécnica de Cataluña, Barcelona

Eduardo Leira Sánchez. Ex director del Plan General de Ordenación Urbana, Madrid

Joaquín Medina Wamburg. Facultad de Aquitectura Diseño y Urbanismo, Universidad de Buenos Aires

Zaida Muxí Martínez. Escuela Técnica Superior de Arquitectura, Universidad Politécnica de Cataluña, Barcelona

José Joaquín Parra Bañón. Escuela Técnica Superior de Arquitectura, Universidad de Sevilla

Víctor Pérez Escolano. Escuela Técnica Superior de Arquitectura, Universidad de Sevilla

Fernando Pérez Oyarzún. Escuela de Arquitectura y Diseño, Pontificia Universidad Católica, Santiago de Chile Judith Sheine. School of Architecture and Allied Arts, University of Oregon, Portland

Andrés Walliser Martínez. Global Design, New York University, Nueva York

\section{ISSN 2340-177X}

Depósito legal M-13872-2013

(c) de los textos, sus autores

(c) de las imágenes autorizadas

(c) Revista Constelaciones

๑) Escuela Politécnica Superior, Universidad CEU San Pablo

Universidad CEU San Pablo

Escuela Politécnica Superior

Urbanización Montepríncipe, $s / n$

Boadilla del Monte, 28668. Madrid (España)

constelaciones@eps.ceu.es

www.uspceu.es

Edición Edition

Fundación Universitaria San Pablo CEU

Madrid, España

Impresión Printing

VA Impresores

Impreso en España Printed in Spain

Distribución Distribution

CEU Ediciones

Los textos que componen Constelaciones se obtienen mediante convocatoria pública. Para que los trabajos recibidos entren en el proceso de selección de los artículos a publicar deben ser trabajos originales no publicados anteriormene, con una extensión recomendada de 3.000 palabras, título, resumen (un máximo de 150 palabras) y palabras clave (un mínimo de cuatro palabras), en español y en inglés. Tras haber cumplido estos requisitos (y los correspondientes incluidos en las normas editoriales de la revista, disponibles para consulta en formato digital desde el comienzo de la convocatoria), tiene lugar un proceso de revisión y evaluación de los artículos previa aceptación de los mismos para su publicación. Para acometer dicho proceso, y con el fin de asegurar la calidad de los contenidos, la Revista Constelaciones recurre a evaluadores externos a la institución editora y anónimos (cada artículo es evaluado por dos de ellos) encargados de someter a crítica los mismos. Todos los artículos de investigación publicados en esta revista han pasado por dicho proceso. La recepción de artículos se extendió hasta el 30 de Septiembre de 2013. Texts included in Constelaciones are obtained by public announcement. Only original papers that have not been previously published will be included in the process of selection of articles. They should not exceed 3.000 words and should include a title, an abstract (no more than 150 words) and keywords (a minimum of four words), in Spanish and English. After having fulfilled these requirements (and those included in magazine editorial standards, available for consultation from the beginning of the Call for Papers), occurs a process of review and evaluation of articles upon acceptance of them for publication. To undertake this process, and in order to ensure the quality of the contents, Constelaciones turns to external and anonymous evaluators to the institution (each article is evaluated by two of them) responsible for the critic. All the articles published in this journal have undergone this process. The deadline for reception was extended until September 30, 2013.

Todos los derechos reservados. Esta publicación no puede ser reproducida, ni en todo ni en parte, ni registrada, ni transmitida, ni almacenada en ningúna forma ni por ningún medio, sin la autorización previa y por escrito del equipo editorial. En este número se han utilizado algunas imágenes de las que no se ha podido identificar al propietario de los derechos. En estos casos hemos entendido que las imágenes son de libre uso. En caso de identificar alguna de estas imágenes como propia, por favor, póngase en contacto con la redacción de Constelaciones. Los criterios expuestos en los diversos artículos de la revista, son responsabilidad exclusiva de sus autores, y no reflejan necesariamente los que pueda tener el equipo editoral. El equipo editorial de la revista no se responsabiliza de devolver la información enviada a la redacción a no ser que se le solicite expresamente. All rights reserved. This publication cannot be reproduced, in whole or in part, nor registered, transmitted or stored in any form or by any means, without the written permission of the Editorial team, In this issue some images were used without knowing the owner of the rights. In these cases, we have understood that the images are free of use. In case you identify written permission of the Editorial team, In this issue some images were used without knowing the owner of the rights. In these cases, we have understood that the images are free of use. In case you identify
any of these images as your own, please, contact with the Editorial staff of Constelaciones. The opinions expressed in this issues's articles are entirely the responsibility of their authors and are not necessarily shared by the editors of this journal. The publisher don't take responsibility for returning submitted material which is not expressly requested. 


$$
11
$$




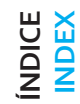

$\stackrel{n}{\sim}$

ร

5

$\curvearrowright$

๙ิ

$\stackrel{n}{=}$

$\bar{m}$
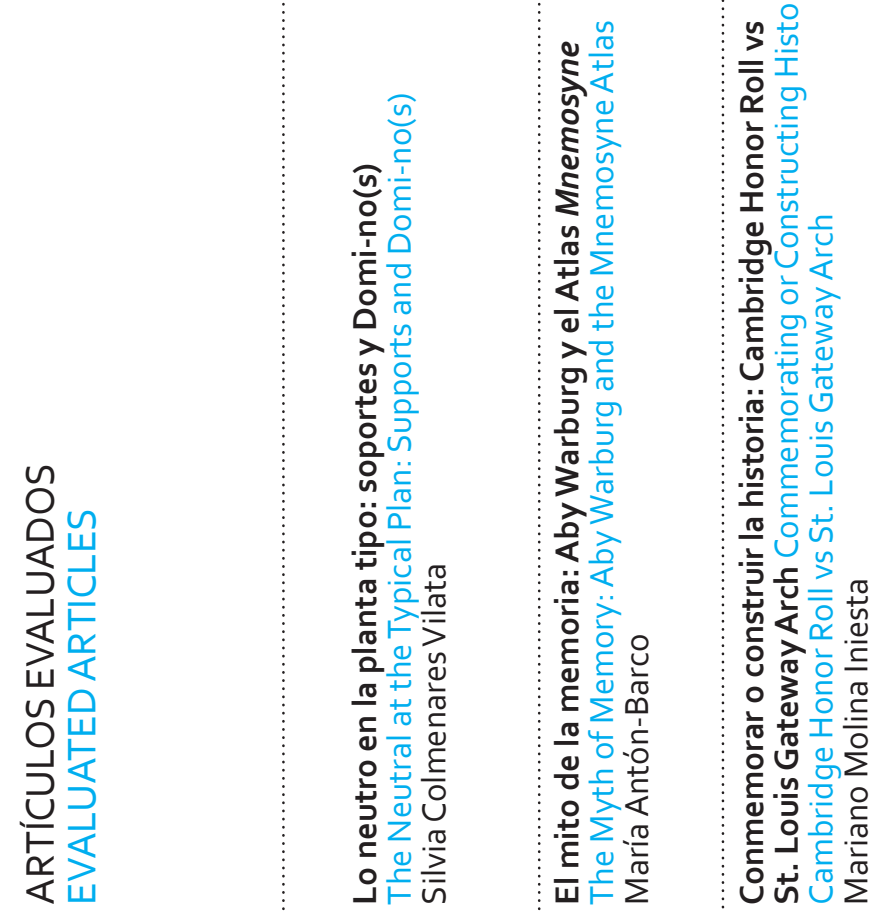

旁 을

‥

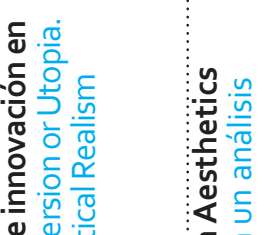

앙

胥苞

$\bar{\Psi}$

宛

일

능홍

区告

음 흠

응 흥

\%

든

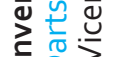

ข

음

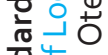

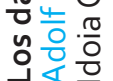

a व

은

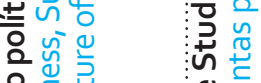

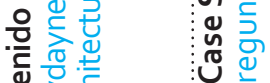

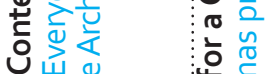

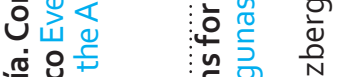

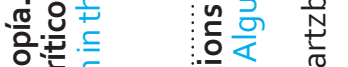

गे

गे० गे ये ज

:

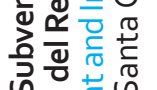

है

ज०

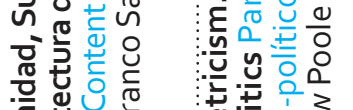

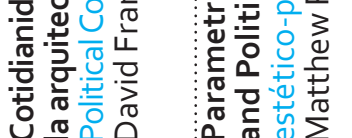

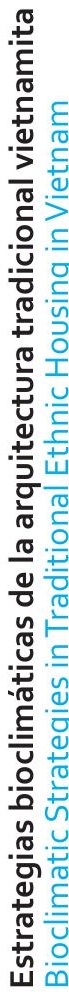

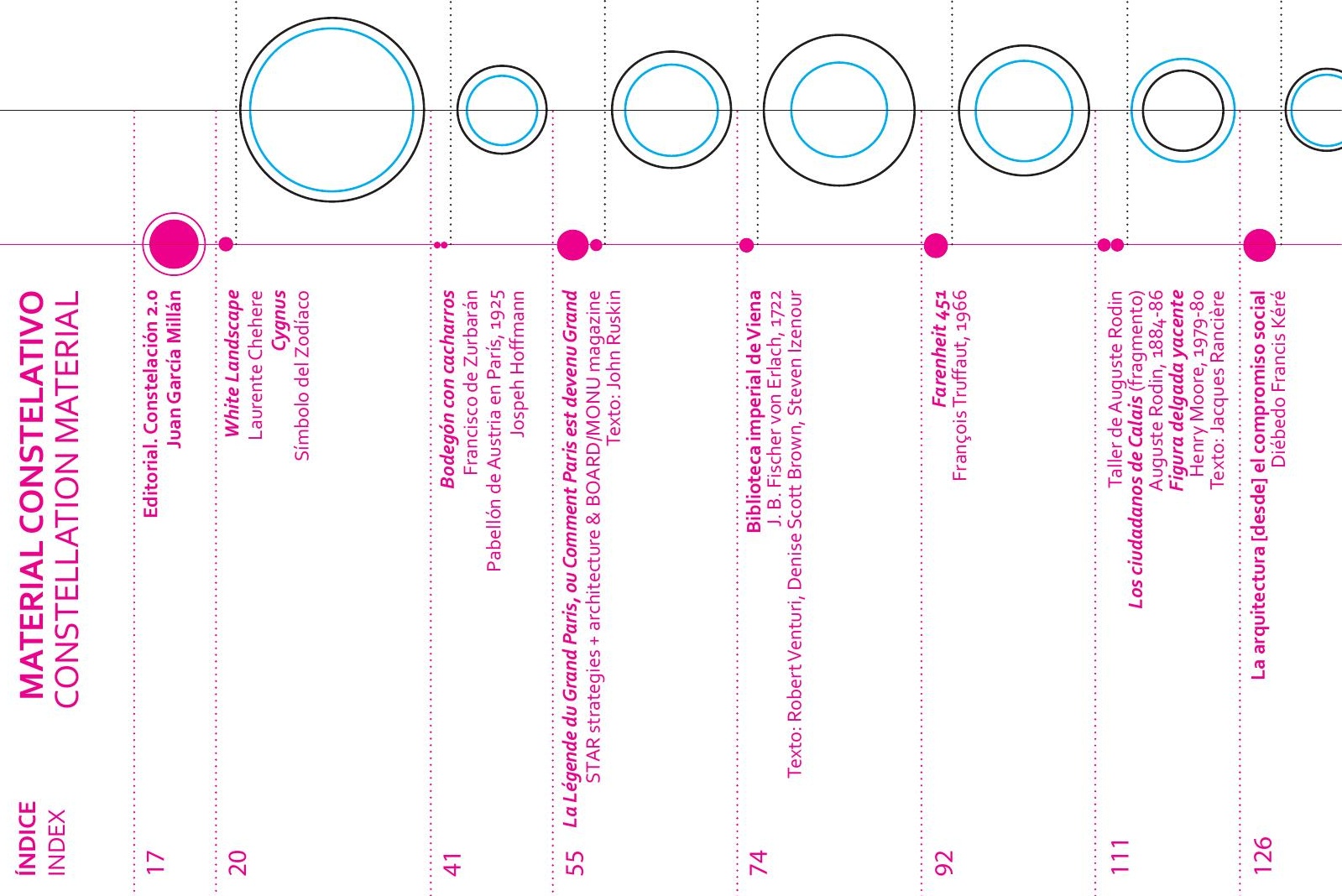

苍

० 


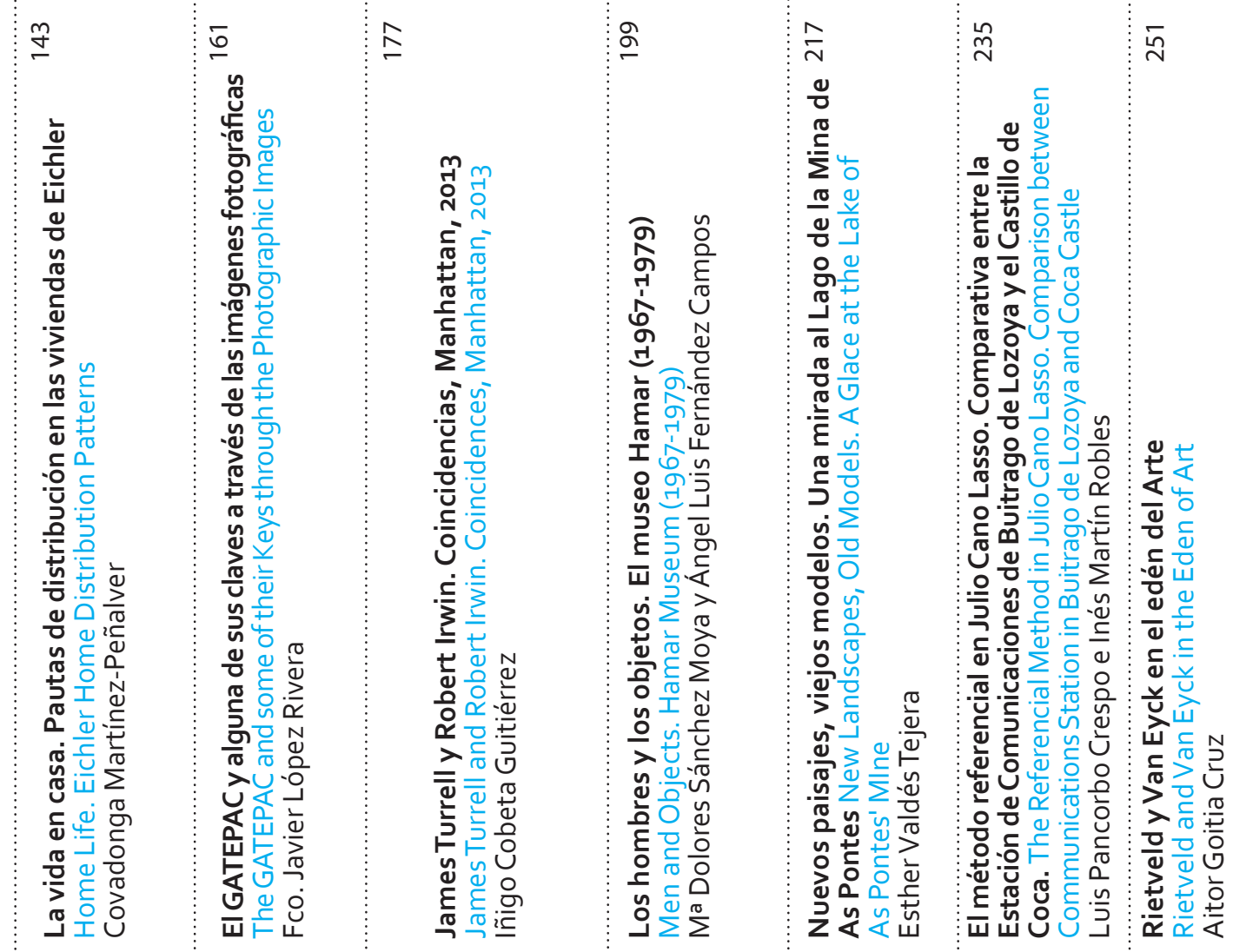
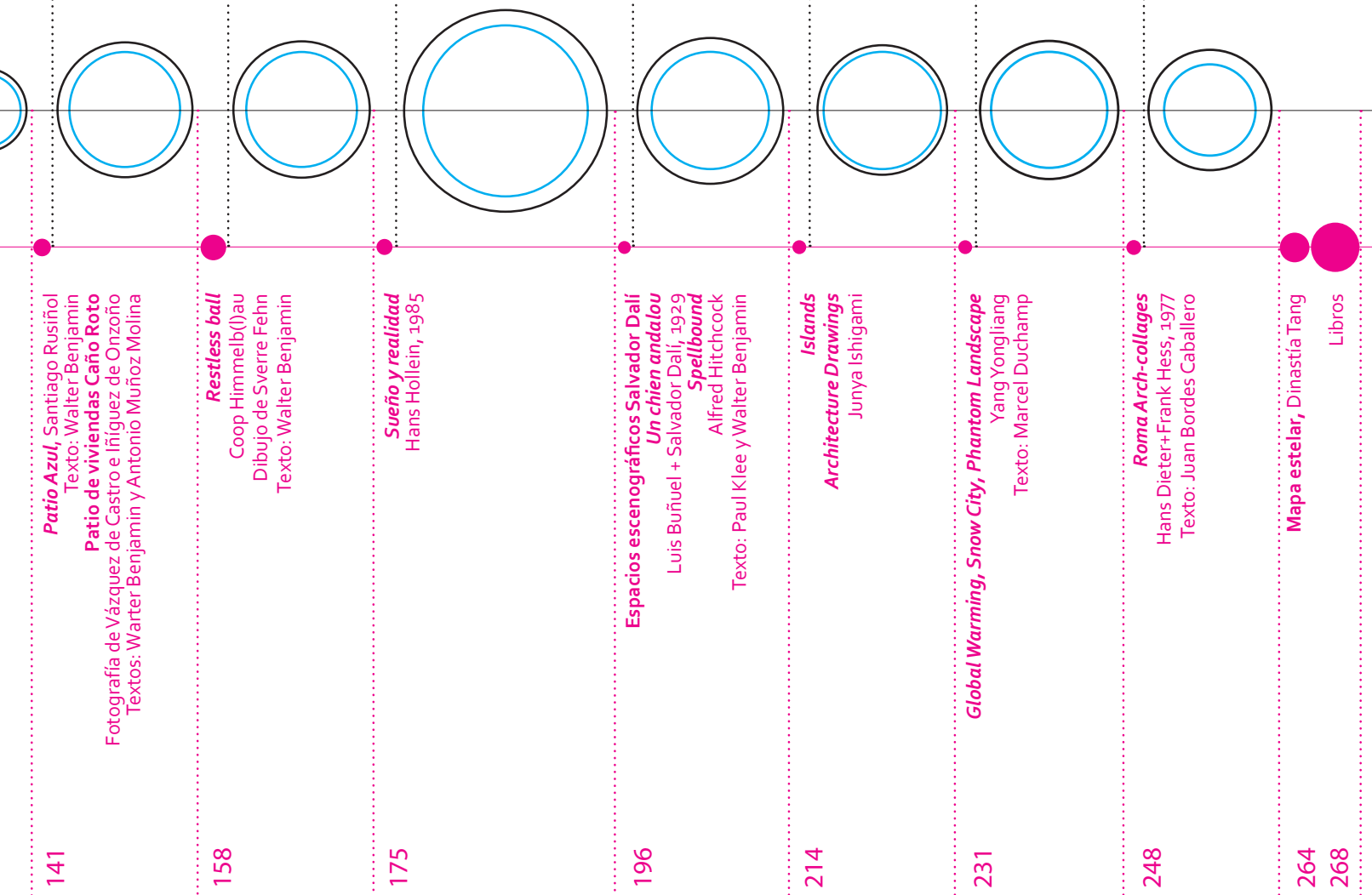


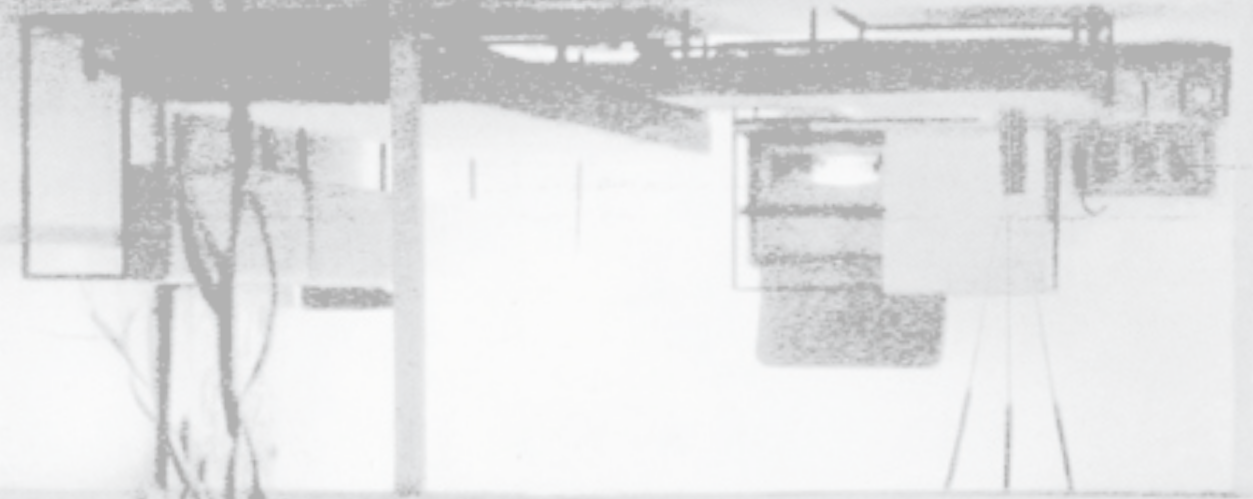

"La claridad de un patio alumbra siempre una REGIÓN del fondo de nuestra MEMORIA... A un patio casi nunca tenemos la SENSACIÓN de llegar por primera vez"

ANTONIO MUÑOZ MOLINA
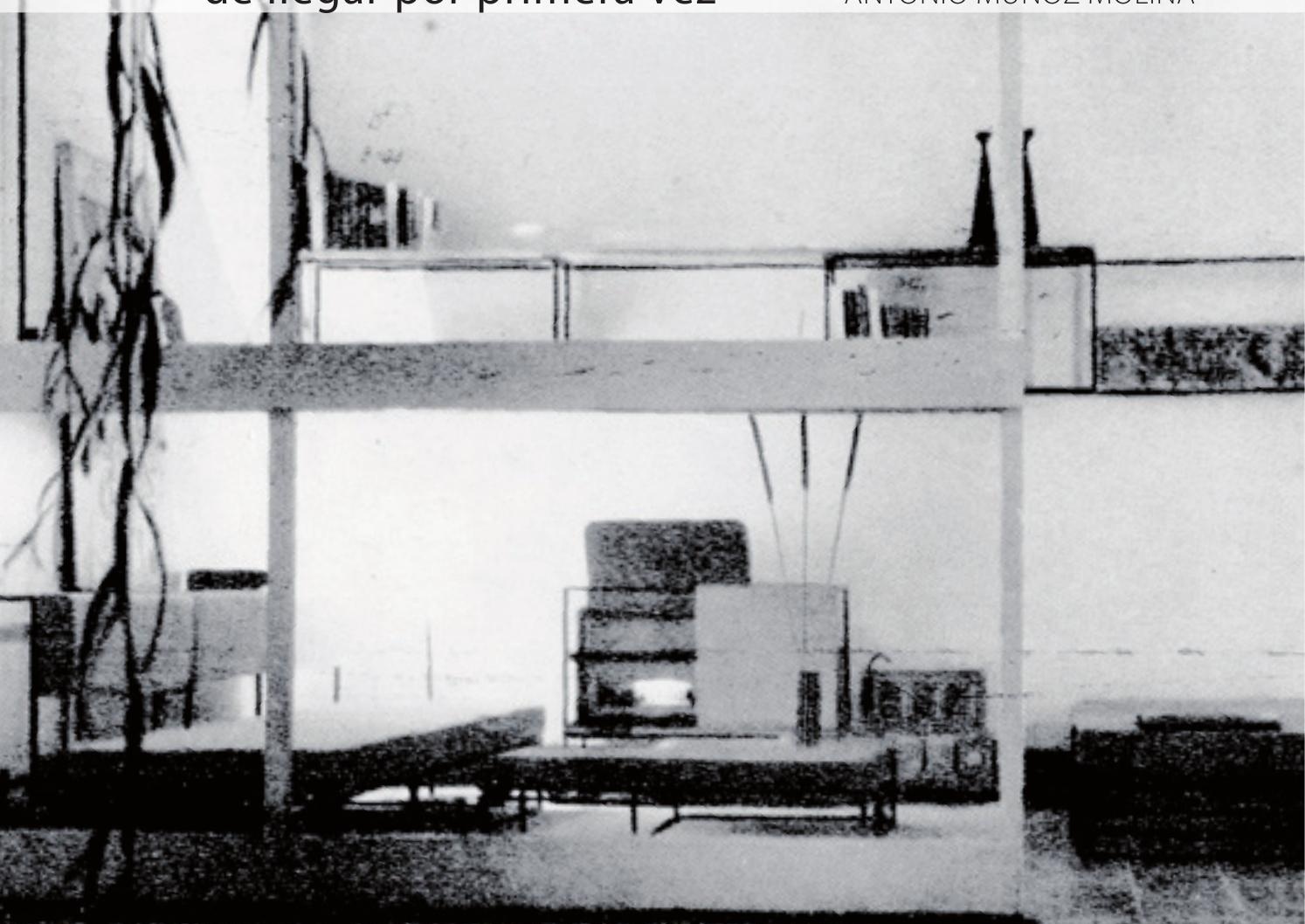

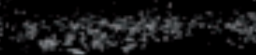




\title{
La vida en la casa. Pautas de distribución en las viviendas de Eichler Home Life.
} Eichler Home Distribution Patterns

\author{
Covadonga Martínez-Peñalver \\ Escuela Politécnica Superior, Universidad CEU San Pablo, Madrid \\ Traducción Translation Carolina Turmo Olivié
}

\section{Palabras clave Keywords}

Distribución, circulación, domestico, abierto, patio, estancia, promover, comercializar

Distribution, circulation, domestic, open, courtyard, room, promote, market

\section{Resumen}

Desde 1949 hasta 1966 el promotor Joseph Eichler construyó aproximadamente 11.000 viviendas en California, comercializando unos modelos de vivienda cuyos criterios organizativos responden al interés por la experiencia cotidiana. Los distintos modelos, proyectados por los arquitectos Anshen \& Allen, Jones \& Emmons y en la última etapa Claude Oakland, comparten ciertas pautas distributivas: doble circulación, habitación exterior y cocina estancial. Estas características responden a una forma de vida acorde, tanto al clima y a la tradición californiana como a una nueva domesticidad en la que la casa no es solo un refugio vital, sino un lugar personal de disfrute, relajación, celebración y juego. Todas estas acciones domésticas quedan retratadas en las fotografías de Ernie Brown con las que se publicitaban las viviendas, mostrando como la riqueza del producto asequible que comercializaba Joseph Eichler es precisamente, la forma de vida que posibilita: la vida en la casa.

\section{Abstract}

From 1949 till mid-sixties, promoter Joseph Eichler built about 11.000 houses in California, marketing home models whose organizational criteria were focused on everyday life. Architects Anshen \& Allen, Jones \& Emmons and in the last years Claude Oakland developed different model houses, which share some of these distribution patterns: double circulation, outside room, and living kitchen. These space characteristics respond to the Californian climate and tradition, but also to a new domesticity that after the Second World War epitomized the American dream, a domesticity in which the house is not only a shelter but a personal space for enjoyment, relaxation, celebration and play. All these domestic actions were portrayed in the photographic work of Ernie Brown used to promote and sell the Eichler homes, showing that the main triumph of the affordable product commercialized by Eichler was the way of life it enabled: a home life. 
Tras la segunda guerra mundial la vida cotidiana que anhelaban los potenciales clientes a los que se dirigían promotores como Joseph Eichler se centraba en la casa. (Fig. 1) La vivienda supera su condición de refugio vital para convertirse en el escenario de las diversas acciones domésticas, entre las cuales se cuentan todo tipo de actividades que expresen la personalidad de cada individuo. La necesidad de abordar el proyecto doméstico desde la atención a esta nueva cotidianeidad de la acción doméstica estaba presente en el contexto cultural arquitectónico. En julio de 1944, por ejemplo, Charles y Ray Eames publican en la revista Arts \& Architecture un diagrama que muestra algunas de las acciones cotidianas que la casa debe poder albergar: jugar a las cartas, leer el periódico, retozar en el sofá, tocar el violonchelo, pintar, preparar unos cócteles o hacer el indio; todas ellas actividades de divertimento personal que expresan y desarrollan la identidad de cada individuo. La casa debe satisfacer el anhelo muy califor-

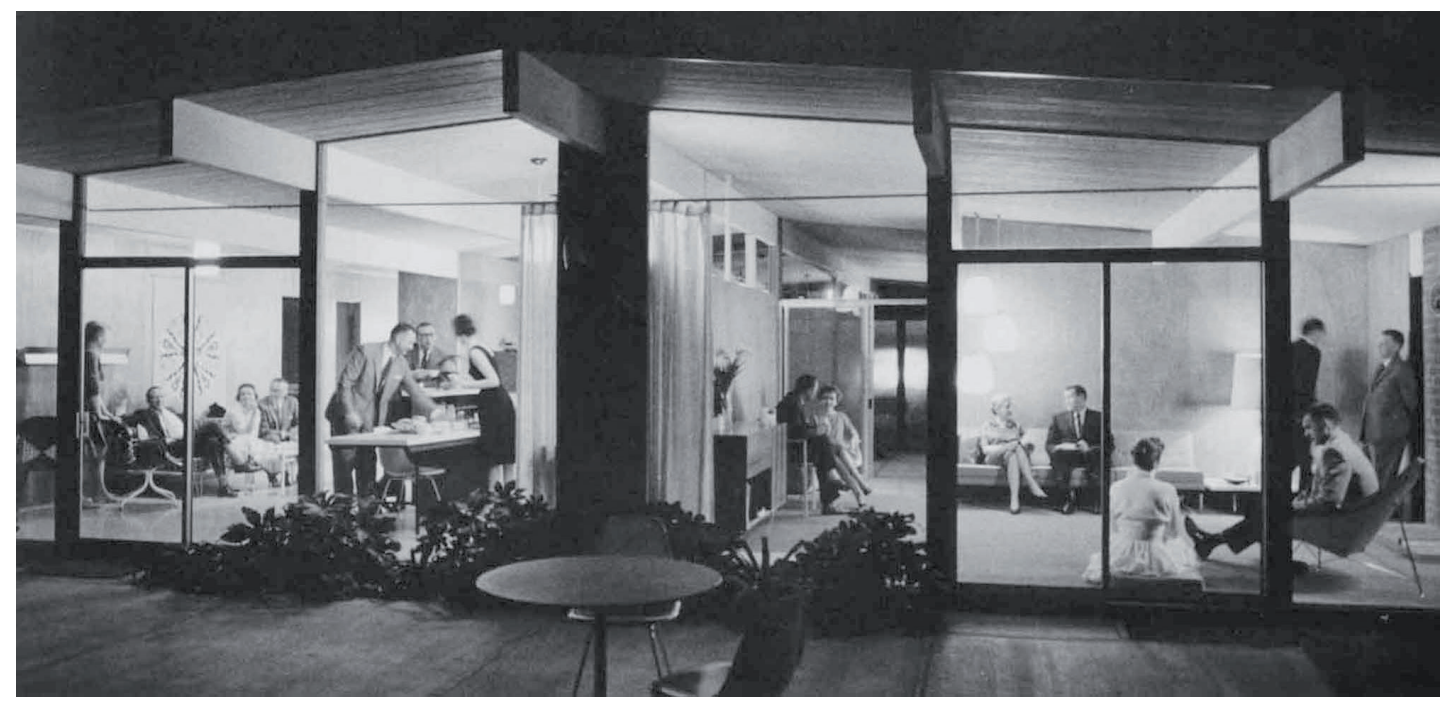

Fig 1. Braun, Ernie: The wonderful world of Eichler.

After the Second World War the daily life longed for by the potential clients of the developer Joseph Eichler was mainly focused on the home. (Fig. 1) Housing upgrades its condition from life shelter to a stage in which different domestic actions take place, including all kind of activities expressing individual personality. The need to approach the domestic project from the awareness of this new everyday life of the domestic action was present at the architectonic cultural context of the time. For instance, on July 1944, Charles and Ray Eames published a diagram on the Arts \& Architecture magazine that shows some of the daily actions that a house must hold: playing card games, reading the newspaper, hanging out on the sofa, playing cello, painting, making some cocktails or fooling around; all of the personal entertainment activities that express and develop each individual's identity. The home must satisfy the -quite- californian desire of freedom to do whatever the inhabitants feel like doing. (1) This concept was at the heart of the projects developed for the Eichler Homes: "the design philosophy of Eichler living has always been that the home should fulfill one's inner desire for happy, lighthearted everyday freedom”. (2) (Figs. 2-4)

The Eichler Homes' marketing reinforces the idea of the home as a place for personal enjoyment. The homes were shown in use both in the domestic scenes captured by the photographer Ernie Braun, as on the display units, decorated by the designer Matt Kahn. In either case, it displayed the capacity of these dwellings to hold any everyday 

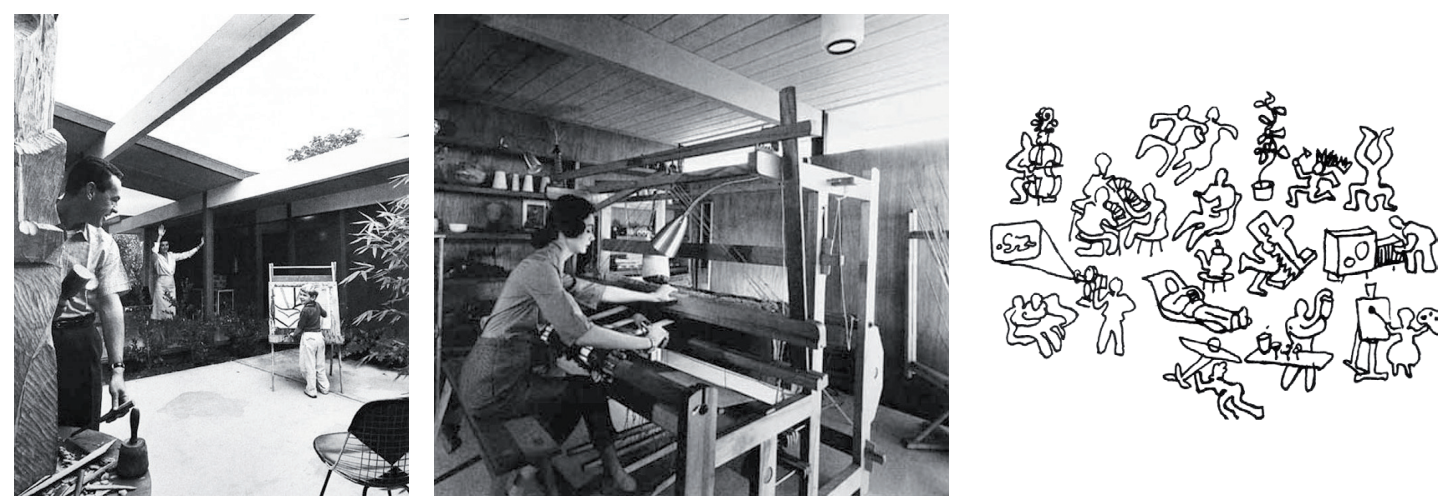

Fig 2. Braun, Ernie: Spare bedroom for at-home crafts designed by Matt Kahn, 1954. Fig 3. Braun, Ernie: Atrium art. Sunnyvale, 1959. Fig 4. Eames, Charles \& Ray: What is a house?, 1944.

niano de dar la libertad a sus habitantes de hacer aquello que sea lo suyo. (1) Este objetivo estaba en la propia génesis de los proyectos desarrollados para Eichler Homes: "the design philosophy of Eichler living has always been that the home should fulfill one's inner desire for happy, lighthearted everyday freedom". (2) (Figs. 2-4)

El marketing de las viviendas de Eichler Homes refuerza esta idea de la casa como lugar de disfrute personal. Las viviendas se mostraban en uso tanto en las escenas domésticas retratadas por el fotógrafo Ernie Braun, como en las casas piloto, cuya decoración realizaba el diseñador Matt Kahn. En ambos casos se muestra la capacidad de las viviendas de Eichler para dar cabida a cualquier actividad de la vida cotidiana. Las fotografías de niños jugando, de una familia charlando o de celebraciones con invitados muestran la casa en un estado natural, disfrutada por una familia cualquiera. Las casas piloto con muebles que incluyen caballetes de pintura en el patio o un telar en una estancia, tratan de mostrar cómo la casa tiene cabida para que esa familia cualquiera desarrolle en ella su creatividad e identidad propia. (3) (Figs. 5, 6)
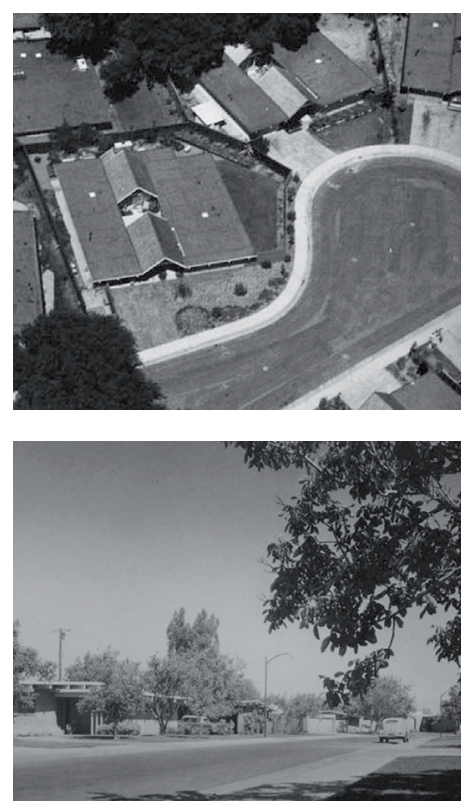

Fig 5. Braun, E.: Eichler Homes in Lucas Valley development, San Rafael, 1965.

Fig 6. Braun, E.: Eichler Homes streetscape, 1950’'s.

activity. The pictures of kids playing, of a family chatting or having some guests over presented the home in its natural state, enjoyed by any given family. The furnished display units with a paint easel in the courtyard or a loom in a lounge are trying to convey how any family may develop its creativity and its own identity in this house. (3) (Figs. 5, 6)

The Eichler housing standards are therefore born with the desire to provide the general public an open structure that allows the everyday enjoyment of the domestic space. An open floor concept appears in every model of spatial organization, generally identified with the freedom of use, in which the various spaces concatenate generating multiple relations between rooms, including the outside areas, treated like any other domestic space. The exterior rooms belong to a non-specialised or univocal type of use, such as multipurpose, retreat, gallery or hobby; rooms that offer freedom and versatility to the user, which may colonize the house by launching its own domestic dynamics. The kitchen is part of this concatenated spatial system, overcoming its condition of workplace to become another living space at the house. Despite their differences, all models share these organizational criteria. All of them are developed based on the awareness of a way of life whose domesticity determines its spatial organization, as we may see going through the distribution patterns defining them: 
Los modelos de vivienda de Eichler nacen por tanto con la voluntad de poner al alcance del gran público una estructura abierta que posibilite el disfrute cotidiano del espacio doméstico. Identificada con la libertad de uso, aparece en todos los modelos una organización espacial de planta abierta, en la que los distintos espacios se concatenan generando múltiples relaciones entre estancias, incluidas las exteriores que aparecen como un espacio doméstico más. Las estancias exteriores pertenecen a un tipo de espacio cuyo uso no es unívoco ni especializado, como las salas multipurpose, retreat, gallery o hobby; estancias que ofrecen libertad y versatilidad al usuario, que puede colonizar la casa mediante la puesta en marcha sus propias dinámicas domésticas. La cocina participa de este sistema de espacios concatenados, superando su condición de centro de trabajo para convertirse en un espacio estancial más de la casa. Todos los modelos por encima de sus diferencias comparten estos criterios organizativos. Todos ellos están desarrollados desde la atención a una forma de vida cuya domesticidad determina su organización espacial, como veremos repasando sobre ellos las pautas distributivas que los definen:

Doble circulación. En los modelos de Eichler la doble circulación o circulación en anilllo aporta riqueza en la forma de usar el espacio doméstico, relaja la especialización unívoca en un solo uso de cada estancia y genera sensación de amplitud poniendo en relación visual diferentes ámbitos de la casa. (Fig. 7)

En el modelo M-1505, un proyecto de Quincy Jones y Frederick Emmons estrenado con éxito en 1963, en Lucas Valley, el criterio de doble circulación se aplica generando varias circulaciones en anillo que establecen múltiples relaciones entre las distintas estancias y posibilitan distintos usos. La cocina, por ejemplo, se relaciona con el salón mediante una doble circulación, o bien a través del comedor, o bien a través de la sala multipurpose. Esta sala multipurpose participa a su vez de otra circulación en anillo que atraviesa el patio, llamado en las Eichler Homes atrium, conectando con las estancias loggia y retreat. Esta circulación hace del atrium una estancia más de la casa, independientemente de su condición de espacio exterior, un distribuidor que relaciona directamente los espacios multipurpose y retreat. La habitación retreat puede formar parte así, de este conjunto de espacios estanciales

Double circulation. On Eichler models, double circulation or ring circulation adds richness to the way domestic space is used. It unwinds the univocal specialization of having a single use in each space and creates a feeling of openness by visually connecting different areas of the house. (Fig. 7)

On the M-1505 model, a Quincy Jones and Frederick Emmons project successfully released in 1963 at Lucas Valley, the double circulation criteria was applied by generating various ring circulations that set multiple room relationships and enable several uses. For example, the kitchen is connected with the living room by a double circulation either through the dining room or through the multipurpose room. At the same time, this multipurpose room participates into another ring circulation that goes through the patio -called atrium on the Eichler Homes- connecting with the loggia and retreat rooms. Due to this circulation, the atrium is perceived as another room of the house, despite its outdoors condition. It is a hallway that connects directly the multipurpose and retreat spaces. This way the retreat room can either be part of this group of living areas or communicate with the bedroom through an alternative circulation through the restroom. This last situation creates the possibility to connect the use of the retreat room to the bedroom, generating an autonomous environment, independent from the rest of the bedrooms, a very successful option for parents. Therefore, rooms overcome the single-use specialization by proving their capability of assuming the everyday 
o relacionarse con el dormitorio a través de otra circulación alternativa a través del baño. Esta última situación hace posible que su uso se ligue al de la habitación, generando así todo un ámbito autónomo independiente del resto de dormitorios, posibilidad que fue muy exitosa entre padres. Las distintas estancias superan así su especialización unívoca en un solo uso, mostrando capacidad para asumir distintas actividades cotidianas y dejan-

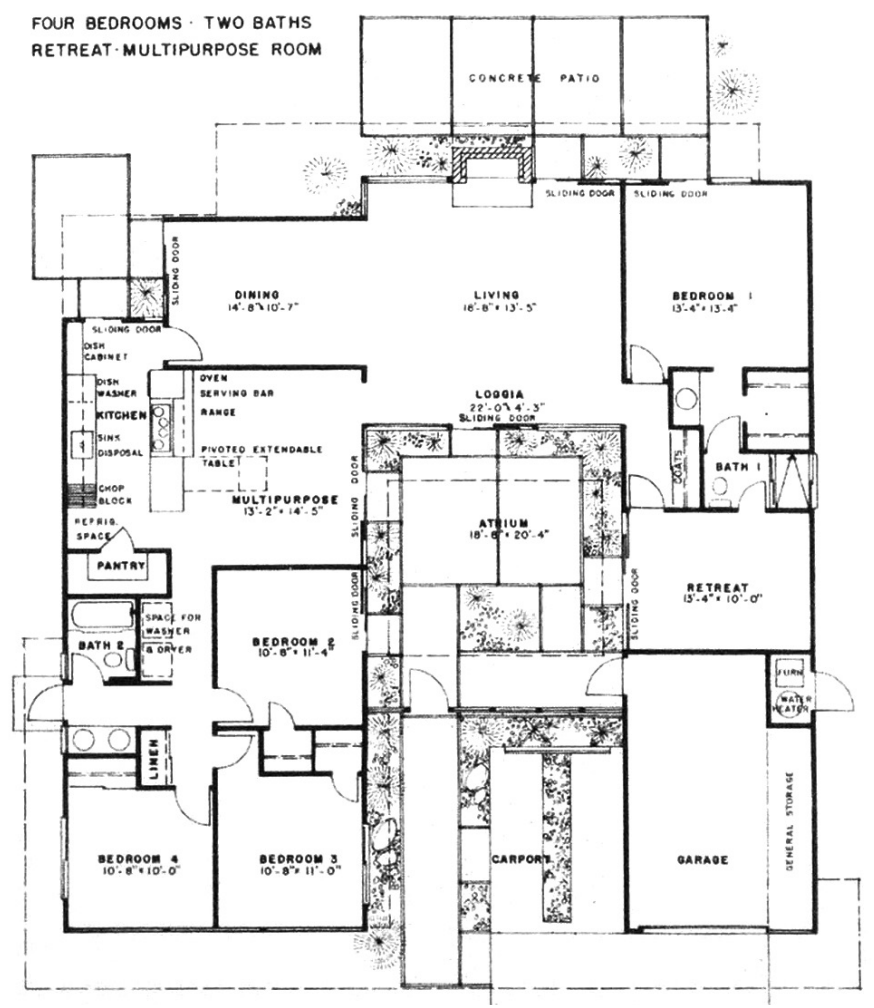

Fig 7. Jones, Quincy; Emmons, Frederick: Modelo M- 1505, 1963.

activities and leaving room for use interpretation that allows the individual to win over the domestic space. The individual will accomplish it not only colonizing the space with its personal objects but also creating its own sequence of day-to-day activities. (Figs. 8, 9)

On the MJ-1864 model -brought out a year late- living room, dining room, multipurpose room and kitchen are related in a ring circulation with a small space called hobby room. This name already emphasizes the festive and personal character that the projects' domesticity wants to convey. The central location of the courtyard that links all areas of the house provides greater richness in the usability of domestic space as all rooms are involved in a large double circulation due to the central location of the courtyard that links all areas of the house. For instance, you can even see the living room from the smallest of rooms, in a long perspective that encompasses the entire house. Besides allowing different forms of household use, the circulation through the yard generates visual amplitude in the perception of space.

Exterior room. The courtyard -called atrium by the Eichler Homes marketing team- became a hallmark of the brand, being incorporated into virtually every model since 1958. (4) The courtyard connected with a building tradition typical of the Californian context, converting an outdoor space into the center of the household that is treated as another room. 
do así cierto margen a la interpretación en el uso que permite al individuo apropiarse del espacio doméstico, haciéndolo propio mediante la creación de sus propias dinámicas cotidianas y no sólo a través de su colonización con sus objetos personales. (Figs. 8, 9)

En el modelo MJ-1864, lanzado al mercado un año después, se relacionan en una circulación en anillo salón, comedor, sala multipurpose y cocina con un pequeño espacio llamado hobby room, evidenciando con su nombre de forma ya inequívoca el carácter lúdico y personal que quiere posibilitar la domesticidad de estos proyectos. Aportando mayor riqueza en las posibilidades de uso del espacio doméstico, todas las estancias participan de una gran doble circulación, gracias a la ubicación central del patio, que pone en relación todos los ámbitos de la casa. Así, por ejemplo, desde la más pequeña de las habitaciones se puede ver incluso el salón, en una perspectiva larga que abarca toda la casa.

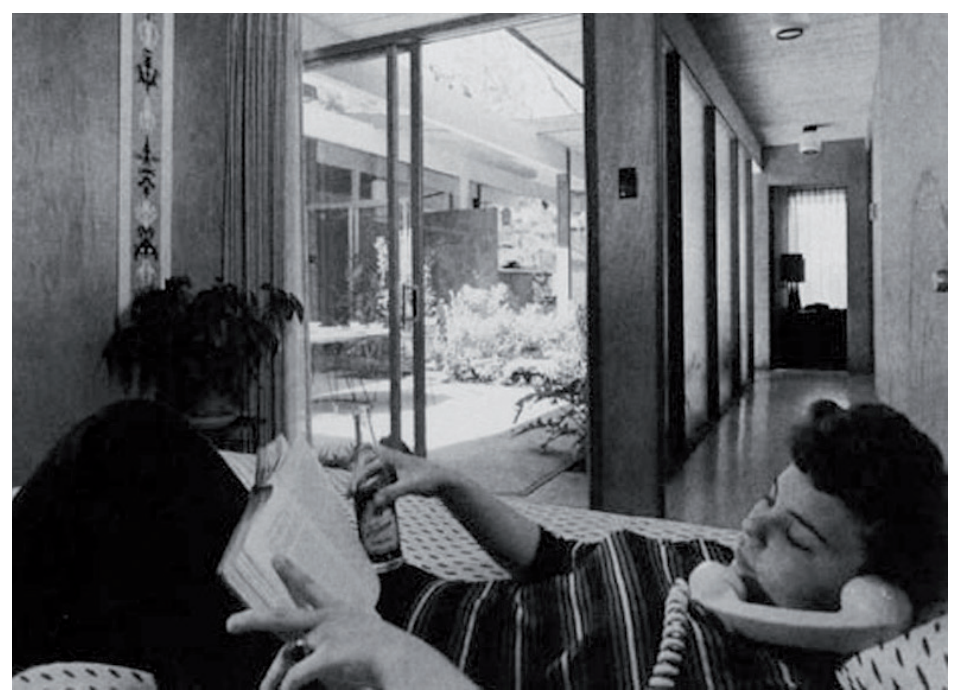

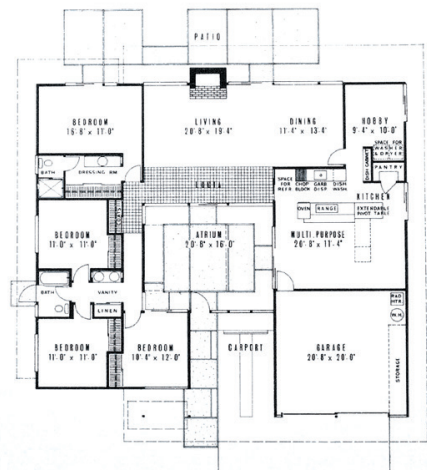

Fig 8. Jones, Quincy; Emmons, Frederick, "Modelo MJ- 1864", 1964.

Fig 9. Braun, Ernie: Bedroom, 1954.

Both for the perception of amplitude it gave and for the possibility of usage created, the courtyard provided a luxury plus to homes that were sold at very affordable prices. (Figs. 10, 11)

Interpreting the patio's outdoor space as just another room of the house connects with the Californian tradition of spending daily life outdoors, whose origin is in the first Mexican ranches, with a U-shaped distributed around a courtyard. Daily use of outdoors domestic spaces also rests on the mythology of the region, based on incredible stories about the benefits that the Californian climate exerts on the welfare of individuals. (5) The Californian climate definitely favours the appropriation of outer space and its everyday use for different purposes, thus the courtyard of Eichler Homes is not just a symbol of the company, but also somehow the symbol of a domestic culture specific to the Californian context. (Figs. 12, 13)

Eichler incorporates the idea of an outside room on every model, understanding that this space is an essential room in the house. The steel structure X-100 model, an experimental and iconic house designed by Quincy Jones and Frederick Emmons in 1956, features two indoor gardens as one of its great attractions. "Two interior living gardens become part of the X-100 itself", (6) as written in its descriptive memory. And so it is; the game garden and the entry garden are also part of the ring circulation that structures the project around an opaque service center. Therefore, they are two more rooms of the house; but its character 
La circulación a través del patio, además de posibilitar distintas formas de uso de la casa, genera amplitud visual en la percepción del espacio.

Habitación exterior. El patio, llamado atrium por el equipo de marketing de Eichler Homes, se convirtió en seña de identidad de la marca desde su incorporación a prácticamente todos los modelos desde 1958. (4) El patio conectaba con una tradición constructiva propia del contexto californiano, atrapando un espacio exterior en el centro de la casa que se entiende como una estancia más. Tanto por la percepción de amplitud que daba como por los usos que posibilitaba, el patio aportaba un plus de lujo a unas viviendas que se comercializaban a precios muy asequibles. (Figs. 10, 11)

Entender el espacio exterior del patio como una estancia más de la casa entronca con la tradición californiana de hacer vida cotidiana al aire libre,

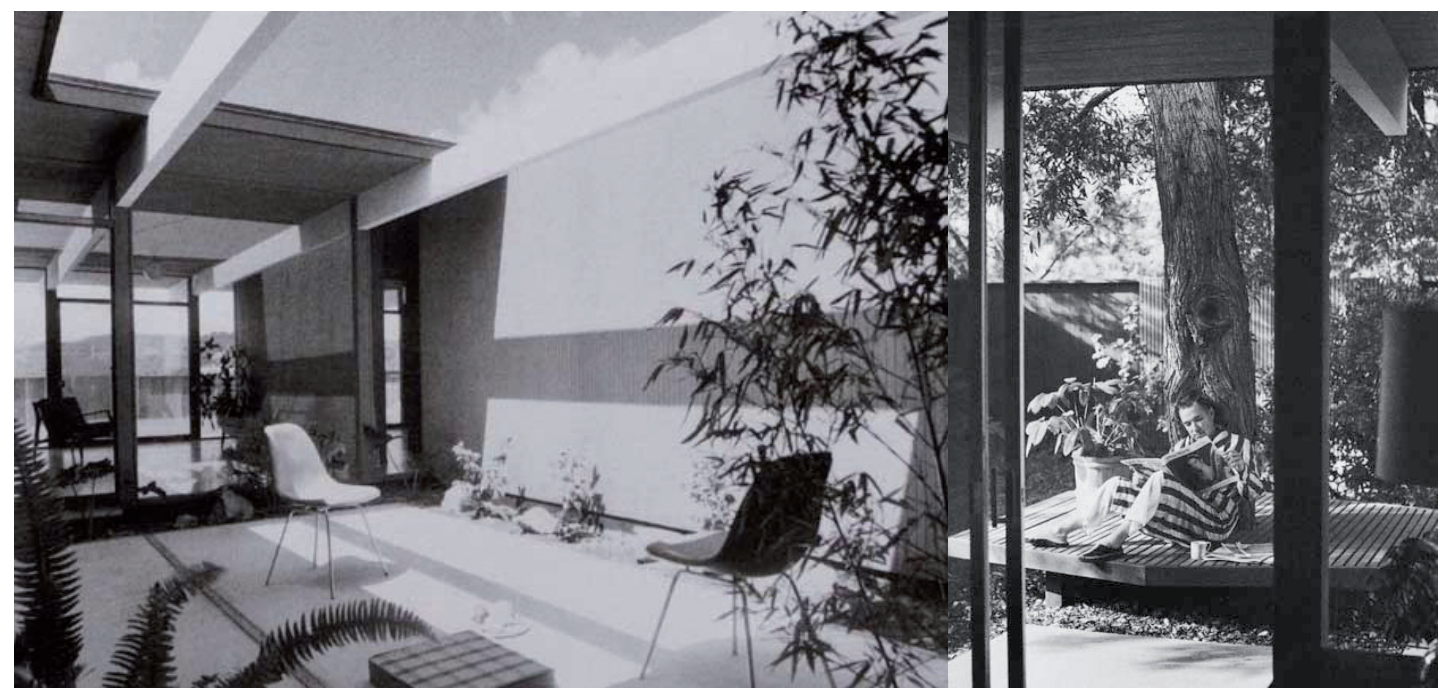

Fig 10. Braun, Ernie: Atrium.

Fig 11. Braun, Ernie: Man reading newspaper.

-with daylight thrown by skylights, abundant vegetation and an organic drawing on the ground identical to the pool drawingis the one of an outdoor room. The concept of life in this house seeks a meeting point between indoors comfort and outdoors openness: "unconfined space within the walls blending with convenient, livable, private outdoor spaciousness". (7) (Fig. 14)

In the family home that Claude Oakland projected for Eichler in 1972, a particular project outside the promotion channels of Eichler Homes, the search for a spatial organization with the openness and the character of an exterior determines the arrangement of rooms in four groups, releasing between them a cruciform space with a courtyard in the center. The arms of this cross, which host the living spaces of the house, have the status of an outer space. Their enclosures, overlooking both the garden and the patio, are floor to ceiling windows that blur the boundary, contrasting with the walls of the rooms and service rooms groups that are much more opaque. Therefore the house seems to be a set of four pieces disaggregated in an indoor garden that has the openness and character of an exterior space. (Fig. 15)

The amplitude generated by an outside space is especially relevant in the lifestyle promoted by more modest models, such as the E-111, developed by Robert Anshen and William Allen in 1959. In it, the atrium room works as a large central room that connects the different parts of the house and, by creating cross visuals, makes the space look larger than it actually is. (Figs. 16, 17) 


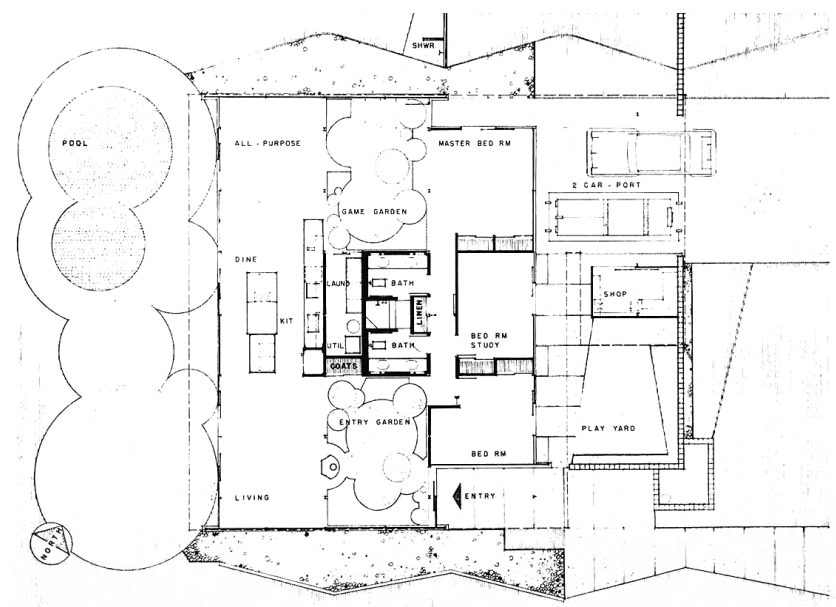

cuyo origen está en los primeros ranchos mejicanos con su distribución en $\mathrm{U}$ alrededor de un patio. El uso cotidiano de los espacios domésticos exteriores se sustenta también en la propia mitología de la región, basada en historias increíbles sobre las bondades que ejerce el clima californiano sobre el bienestar de las personas. (5) El clima californiano favorece sin duda la apropiación de los espacios exteriores y su uso cotidiano para distintas actividades, por lo que el patio de las Eichler Homes no es solo un símbolo de la compañía, sino que también es de alguna forma el símbolo de una cultura doméstica propia del contexto californiano. (Figs. 12, 13)

Eichler incorpora la idea de habitación exterior en todos los modelos, entendiendo que este espacio es una estancia esencial de la casa. El modelo de estructura de acero X-100, una casa experimental y emblemática proyectada por Quincy Jones y Frederick Emmons en 1956, incorpora dos jardines interiores, como uno de sus grandes valores. "Two interior living gardens become part of the X-100 itself”, (6) reza su memoria. Y así es; el game garden y el entry garden participan como el resto de las estancias de una circulación en anillo que estructura el proyecto en torno a un centro opaco de servicios. Son dos es-

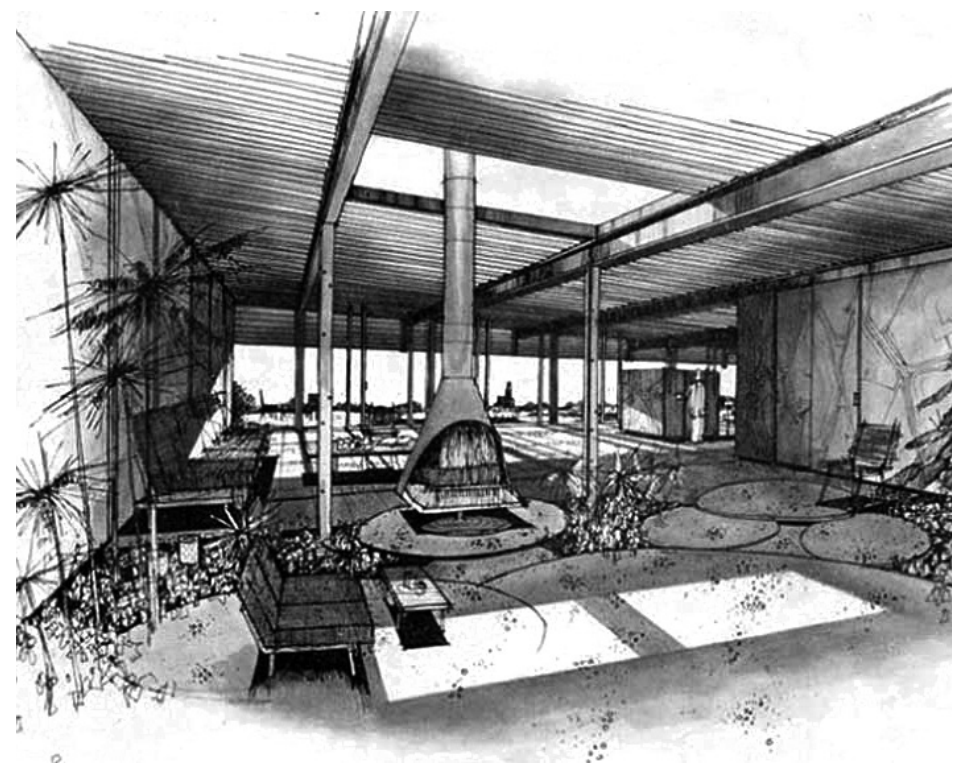

Fig 12. Jones, Quincy; Emmons, Frederick, Modelo X-100, 1956.
Fig 13. Jones, Quincy; Emmons, Frederick, Modelo X-100, 1956. 
tancias más de la casa, por tanto; pero su carácter, con luz cenital arrojada por lucernarios, vegetación abundante y un dibujo orgánico en el suelo idéntico al de la piscina, es el de una habitación exterior. La concepción de la vida en esta casa persigue el encuentro entre la comodidad del interior y la amplitud del exterior: "unconfined space within the walls blending with convenient, liveable, private outdoor spaciousness". (7) (Fig. 14)

En la casa familiar que proyectó para Eichler Claude Oakland en 1972, un caso particular ajeno a los canales de promoción de Eichler Homes, la búsqueda de una organización espacial con la amplitud y el carácter de un jardín exterior determina la disposición de las habitaciones en cuatro paquetes de estancias que liberan entre ellas un espacio cruciforme en cuyo centro hay un patio. Los brazos de esta cruz, que albergan los espacios estanciales

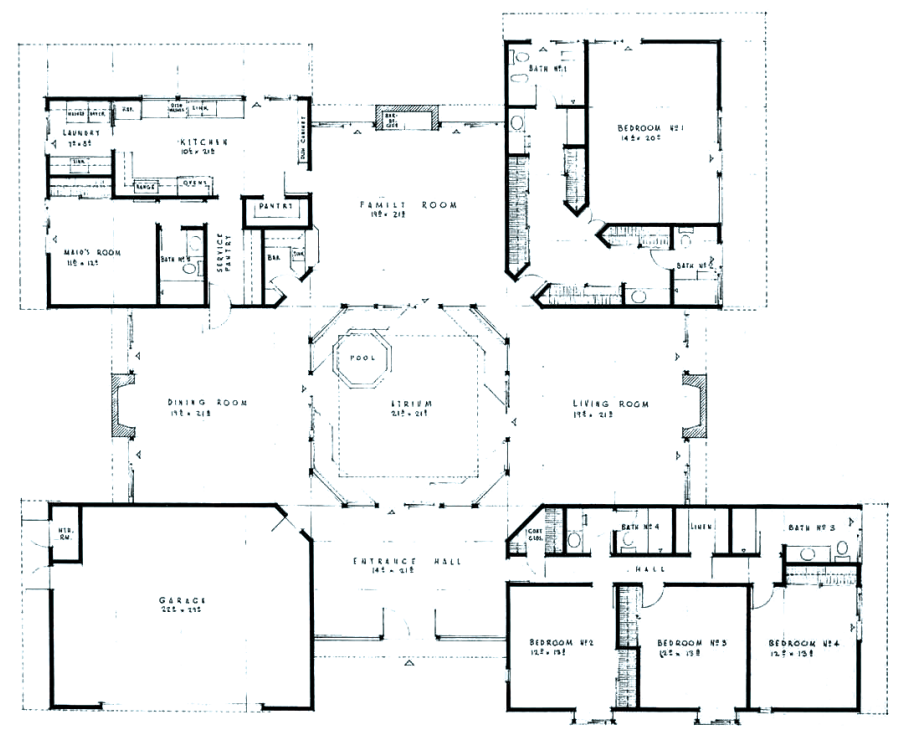

Fig 14. Oakland, Claude. Eichler family house, 1972.

The sloping roof leaning on the patio, a characteristic featured in later models, increased even more the feeling of amplitude and created an identity element for the Eichler homes. But the identity of the atrium depends primarily on their usability. Besides a relaxing place, exuberant garden or leisure area, the ambiguity of this outdoors-indoors room with an undefined purpose gives the choice to use it as a social meeting place. Often, in the Ernie Braun photographs used as advertisement of the Eichler homes, the yard appeared showing a gathering of friends, a party or a family breakfast. In this type of suburban developments where there were still few community spaces, the Eichler homes filled the gap by incorporating a suitable place for meetings and gatherings: the atrium; a room that being private is not completely inside and being domestic do not violate the privacy of the home. (8) Both the amplitude and usability provided by the atrium makes it highly desirable to potential buyers of Eichler homes, who saw in this space an unexpected sense of luxury found in these homes and nonexistent in other mass-produced developments of an affordable price. (Figs. 18, 19)

Living kitchen. Another distributional pattern common to all Eichler models is opening up the kitchen towards the living areas of the house, avoiding its reduction to a mere workspace through its strategic location and its participation in the main circulations of the house. In fact, in most models the kitchen is incorporated into a space called multipurpose room, and renamed by the Parents magazine "the family room", (9) thus becoming a functional and living space. This 
de la casa, tienen carácter de espacio exterior. Sus cerramientos, tanto hacia el jardín como hacia el patio, son vidrios de suelo a techo que desdibujan el límite, contrastando con los cerramientos de los paquetes de habitaciones y servicios que son mucho más opacos. La casa parece ser así un conjunto de cuatro piezas disgregadas en un jardín interior que tiene la amplitud y el carácter de un espacio exterior. (Fig. 15)

La amplitud que genera un espacio exterior es especialmente relevante en la forma de vida que propician modelos más modestos, como el E-111, desarrollado por Robert Anshen y William Allen en 1959. En él, la estancia atrium funciona como una gran sala central que pone en relación las distintas partes de la casa y que generando visuales cruzadas hace parecer el espacio mayor de lo que es. (Figs. 16, 17)

La cubierta inclinada sobre el patio, característica incorporada en modelos posteriores, aumentaba aún más la sensación de amplitud, además de crear un elemento de identidad para las viviendas de Eichler. Pero la identidad del atrium descansa principalmente en sus posibilidades de uso. Además de lugar de relajación, jardín exuberante o espacio de ocio, la ambigüedad de esta estancia exterior pero interior y sin uso definido permite su uso como espacio social

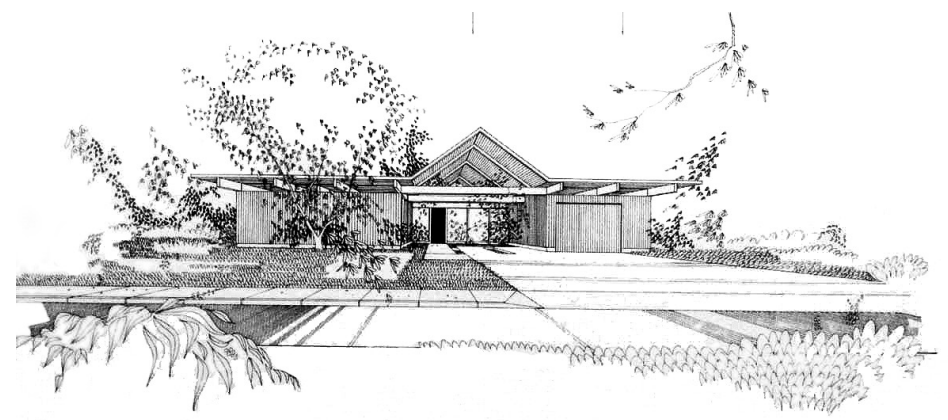

Fig 15. Anshen, Robert; Allen, William, Modelo E- 111, 1959.
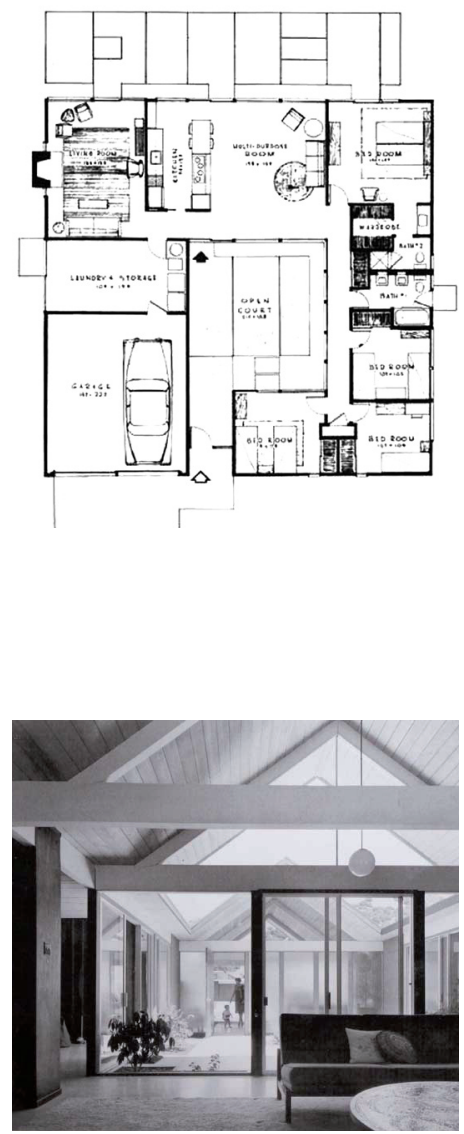

Fig 16. Jones, Quincy; Emmons, Frederick: Modelo MJ-1864, 1964.

Fig 17. Braun, Ernie: Atrium.

distribution promotes a way of life in which everyday chores and childcare are not silent actions of an invisible service, but are carried out from the cult of domesticity by a woman who takes over the whole the house, leading the family life. (Figs. 20-22)

In the Green Gables model -developed by Robert Anshen and William Allen in 1950- which is one of the first models, a desire to link the kitchen to the rest of the house life is already expressed, giving it a double circulation towards the living room, which is accessed across the entry or the dining room and with a direct connection to the garage, the gate to the outside world. Therefore, the kitchen occupies a strategic position from which both the entrances and the private areas are controlled, with views that even allow controlling the terrace with just one look. On the MC-55 model, developed for Terra Linda by Quincy Jones and Frederick Emmons in 1955, the kitchen has again a dual access that allows it to interact with the living room from a position in which the entrances are also controlled. In this model the idea of a space with any use has already appeared -called the all-purpose room- but its position is tangential to the living room and still has no direct relationship with the kitchen. On the MC-34 model, developed by Claude Oakland in 1964, the strategic position of the kitchen turns it into the connection between the living room and the multipurpose space, which at that moment appears as a central space whose size equates in importance to the living room. (Figs. 23, 24) 
de encuentro. Frecuentemente, en las fotografías de Ernie Braun con las que se publicitaban las casas de Eichler el patio aparecía mostrando una reunión de amigos, una fiesta o un desayuno familiar. En este tipo de promociones suburbanas en las hay pocos espacios comunitarios las casas de Eichler compensaban esta carencia con la incorporación de un lugar idóneo para reuniones y encuentros: el atrium; una estancia que siendo privada no es completamente interior y siendo doméstica no vulnera la intimidad del hogar. (8) Tanto la amplitud como las posibilidades de uso que aporta el atrium lo convierten en un extra muy deseable para los potenciales compradores de las viviendas de Eichler, que veían en este espacio una noción de lujo inesperada en viviendas de precio asequible e inexistente en otras promociones en serie. (Figs. 18, 19)

Cocina estancial. Otra pauta distributiva común a todos los modelos de Eichler es la apertura de la cocina hacia los ámbitos estanciales de la casa evitando, mediante su localización estratégica y su participación en las circulaciones principales de la casa, su reducción a un mero espacio de trabajo. De hecho, en la mayoría de los modelos la cocina se incorpora a un espacio llamado multipurpose room, y rebautizado por la revista Parents "the family room", (9) convirtiéndose así en un espacio estancial además de funcional. Esta distribución propicia una forma de vida en la cual las tareas cotidianas de la casa y el cuidado de los niños no son acciones silenciosas de un servicio invisible, sino que se realizan desde el culto a la domesticidad por una mujer que se adueña del conjunto de la casa, liderando la vida familiar. (Figs. 20-22)

En el modelo Green Gables, desarrollado por Robert Anshen y William Allen en 1950, uno de los primeros, se expresa ya una voluntad por vincular la cocina a la vida de la casa dotándola de una doble circulación hacia el salón, al cual se accede cruzando la entrada o el comedor, y de una conexión directa con el garaje, la puerta al mundo exterior. La cocina ocupa por tanto una posición estratégica desde la que se controlan tanto las entradas como las zonas más privadas, con visuales que permiten controlar de un vistazo incluso la terraza. En el modelo MC-55, desarrollado para Terra Linda por Quincy Jones y Frederick Emmons en 1955, la cocina vuelve a tener un doble acceso que le permite relacionarse con el salón desde una posición
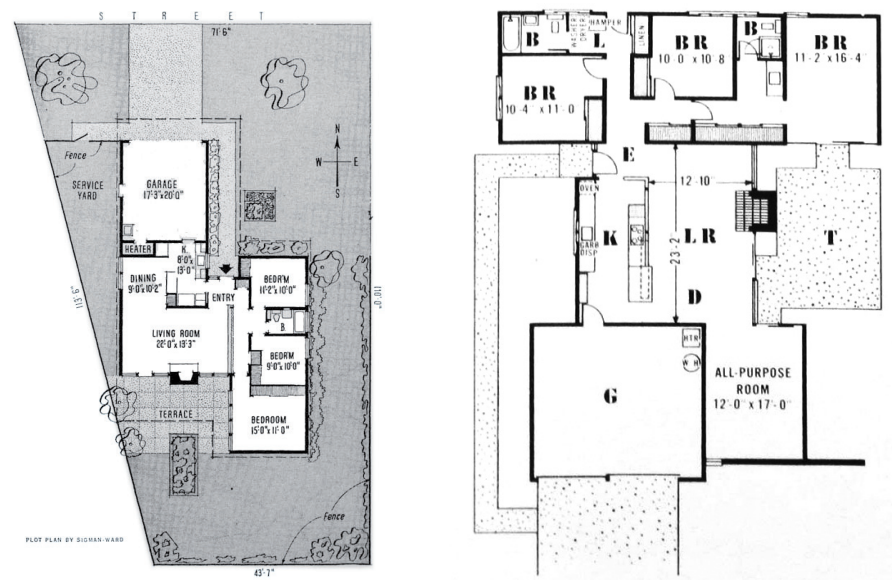

Fig 18. Braun, Ernie: Atrium. Fig 19. Braun, Ernie: Atrium.
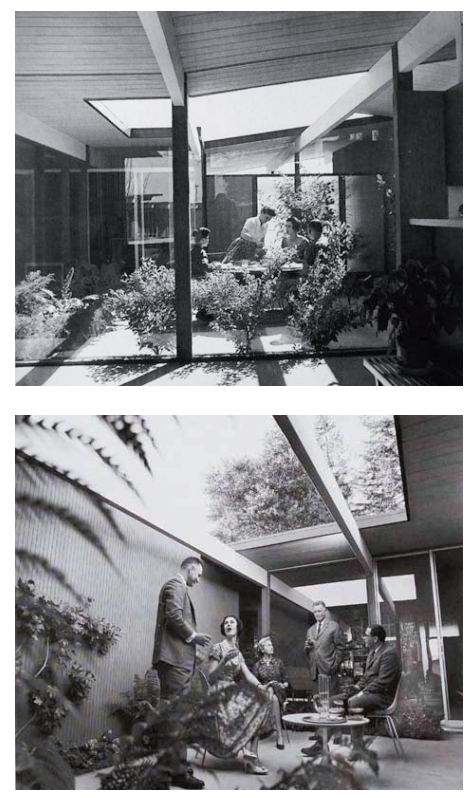

Fig 20. Anshen, Robert; Allen, William: Green Gables, 1950.

Fig 21. Jones, Quincy; Emmons, Frederick: Modelo MC- 55, 1955.

Fig 22. Oakland, Claude: Modelo MC-34, 1964.

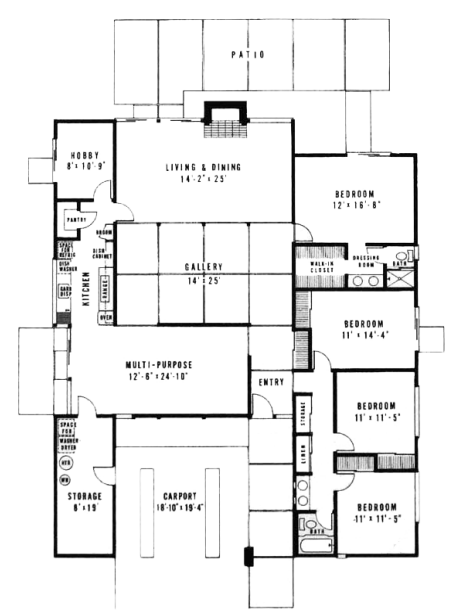


en la que controla también las entradas. En este modelo aparece ya la idea de un espacio para cualquier cosa, llamado aquí all-purpose room, pero su posición es tangencial al salón y todavía no tiene relación directa con la cocina. En el modelo MC-34, desarrollado por Claude Oakland en 1964, la posición estratégica de la cocina la convierte en la unión entre el salón y el espacio multipurpose, que ya aparece como un espacio central cuya tamaño lo equipara en importancia al salón. (Figs. 23, 24)

En todos los casos la cocina tiene vocación de centro de control, desde ella se controla lo que pasa en toda la casa. De hecho, en muchos modelos se incluía entre la cocina y el espacio multipurpose una mesa central conocida como command center. (10) Su posición evitaba que la mujer se situara de

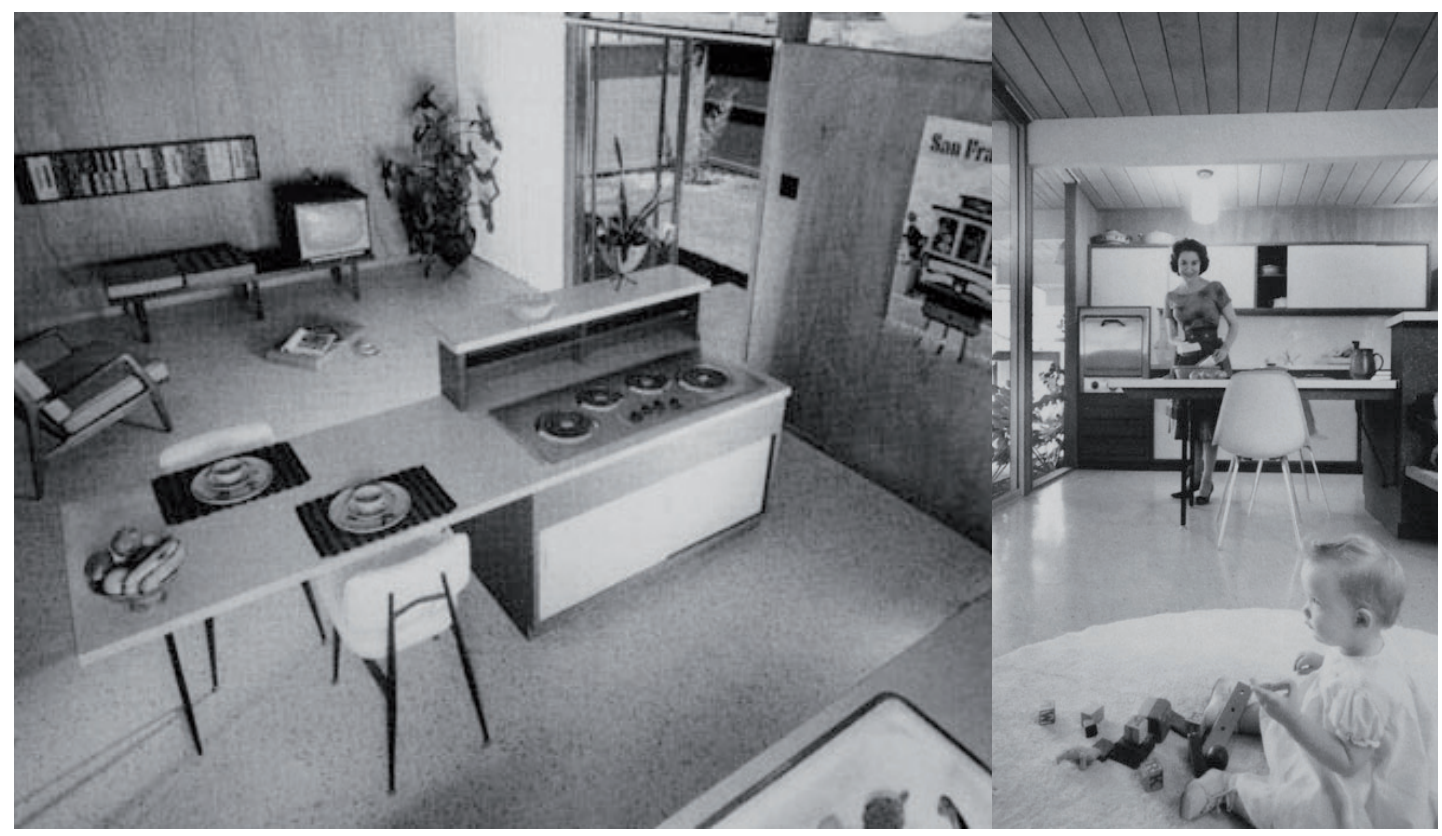

Fig 23. Braun, Ernie: Command center. Fig 24. Braun, Ernie: Multipurpose room.

In any case the kitchen has the role of a control center, a place to control what happens in the rest of the house. In fact, in many models a central table known as command center was included between the kitchen and the multipurpose space. (10) Its position prevented women to be placed backwards to the action, allowing them for instance to perform tasks while controlling their children. Its technification made home tasks bearable for a woman whose role in the family results from a long path originated in works such as Catharine Beecher's, which relates the life of the woman and her family with the design of her home. Therefore, this woman's kitchen is a strategic piece in the circulation, that is involved in house life from a control position and that achieves a room character due to its increasing association with a living room -usually called multipurpose room. (Figs. 25-27)

The day-to-day activities of the family happens mainly in the multipurpose room, an informal place where everything is allowed, a battlefield in some way, where kids can paint, assemble a train circuit or play on the floor without fear of damaging things. A practical place, designed for a practical woman's life, the woman behind these housing models enabling the lifestyle suggested by them. This woman, who has no servants or help with childcare, is relieved of the burden of domestic chores not only by looking for its simplification or reduction but also by learning how to enjoy them. The living kitchen in the Eichler homes exemplarily embodies the change of accent that transforms a chore like cooking into a pleasure or a 
espaldas a la acción, lo que le permitía por ejemplo realizar tareas mientras controlaba a sus hijos. Su tecnificación le daba a la mujer el control de las tareas, llevaderas así para una mujer cuyo papel en la familia resulta de un largo camino originado en trabajos como el de Catharine Beecher, que pone en relación la vida de la mujer y su familia con el diseño de su casa. La cocina de esta mujer, por tanto, es una pieza estratégica en las circulaciones que participa de la vida de la casa desde una posición de control y que adquiere un carácter estancial gracias a su vinculación creciente con un cuarto de estar llamado generalmente multipurpose room. (Figs. 25-27)

El día a día familiar transcurre principalmente en la multipurpose room, un lugar informal donde todo está permitido, un campo de batalla en cierto modo, donde los niños pueden pintar, montar un circuito de trenes o jugar en el suelo sin temor a estropear nada. Un lugar práctico, pensado para la vida de una mujer práctica, la mujer que está detrás de estos modelos de vivienda haciendo posible la forma de vida que sugieren. Esta mujer, que no tiene servicio doméstico ni ayuda con el cuidado de los hijos, es aliviada de la carga del trabajo doméstico no solo buscando su simplificación o reducción sino entendiendo su disfrute. La cocina estancial de las casas de Eichler encarna de forma ejemplar el cambio de acento que convierte una tarea doméstica como cocinar en un placer, o en un hobby. Las fotografías de Ernie Braun, siempre mostrando la casa en uso, ofrece escenas cotidianas en las que la mujer realiza tareas domésticas disfrutando de su casa y sin aparentar ningún esfuerzo. Así la vemos planchando mientras se ríe al ver a su pequeño jugando con un tren, poniendo un plato delicioso en la mesa para su familia, cosiendo mientras charla con sus hijos o hablando por teléfono desde su cocina impecablemente limpia. La idea subyacente está clara: mantener esta casa es un placer. El esfuerzo por entender las tareas domésticas como soportables e incluso placenteras se ancla en una idea de familia en la que la mujer permanece en casa al cuidado de los hijos. Para que no quede duda de que esto es lo mejor que puede desear, la mujer también protagoniza escenas en las que cuida de sus plantas, ofrece fiestas, o lee tranquilamente una revista mientras cuida de su bebé, mostrando como disfruta del día a día en la casa. Gracias al papel de la mujer en la estructura familiar típica a la que se dirigen las casas de Eichler la casa se vive durante todo el día; la vida, de hecho, transcurre
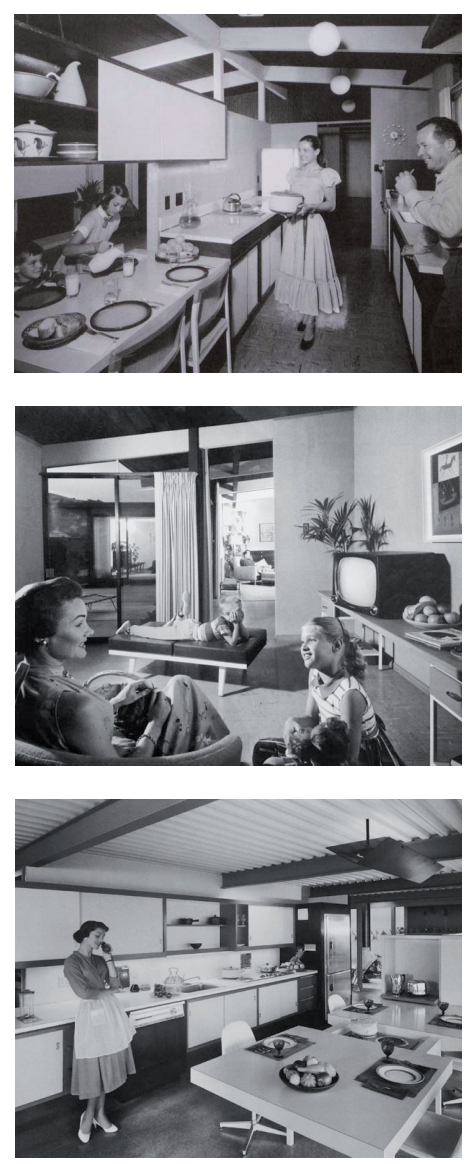

Fig 25. Braun, Ernie: Kitchen.

Fig 26. Braun, Ernie: The Family Room. 1955

Fig 27. Braun, Ernie: Inside the X-100 kitchen. 1957.

hobby. Ernie Braun's pictures, showing always the house in use, provides daily scenes in which women perform household chores and enjoys her home while appearing effortless. So we can see her ironing while smiling at her kid playing with a small train, serving a delicious dish on the table for her family, sewing while chatting with their children or talking over the telephone from her spotlessly clean kitchen. The underlying idea is clear: keeping this home clean is a pleasure. The effort to understand the housework as bearable and even enjoyable is anchored in an idea of the family in which the wife stays at home taking care of children. In order to make clear that this is the best life you could ever dream of, she also stars in scenes taking care of her garden, throwing parties, or quietly reading a magazine while taking care of her children, showing how much she enjoys her daily life at home. Thanks to the women's role in the typical family structure that the Eichler houses are aimed to, home is lived all daylong; life, in fact, takes place in the house. The distribution structure of these models therefore promotes a way of life in which the house is the main stage of family life, and the woman is the main banner. (Figs. 28-30)

In essence, the Eichler homes housing models are developed from the attention to lifestyle. Eichler worked closely with architects who responded to the yearnings of a domestic life centered in the home. This was achieved by providing some freedom in the use of each room by the superposition of different circulations, by satisfying the desire to 
en la casa. La estructura distributiva de estos modelos propicia por tanto una forma de vida en la que la casa es el principal escenario de la vida familiar, y la mujer es su principal estandarte. (Figs. 28-30)

En definitiva, los modelos de vivienda de Eichler Homes están desarrollados desde la atención a la forma de vida. Eichler trabajó estrechamente con arquitectos que supieron responder a los anhelos de una vida doméstica centrada en la casa, propiciando cierta libertad en el uso de cada estancia gracias a la superposición de distintas circulaciones, satisfaciendo el deseo de extender la vida doméstica al exterior, tomando también del exterior criterios espaciales con los que proyectar el interior, y posibilitando una domesticidad del disfrute de lo cotidiano, cuyo principal baluarte es la mujer, la persona que mantiene el orden y controla lo que pasa desde su estratégica cabina de mando, la cocina. La flexibilidad de la planta abierta, el uso del exterior como un espacio doméstico y la inclusión de la cocina en la vida estancial de la casa fueron criterios distributivos con la capacidad de determinar la vida en la casa, entendiendo que el proyecto doméstico no es sólo un reflejo de un modo de vida dado, ni un producto cultural ajeno a la producción de cultura, sino que es el laboratorio en el que propiciar nuevas dinámicas cotidianas que redefinen el modo de vida.
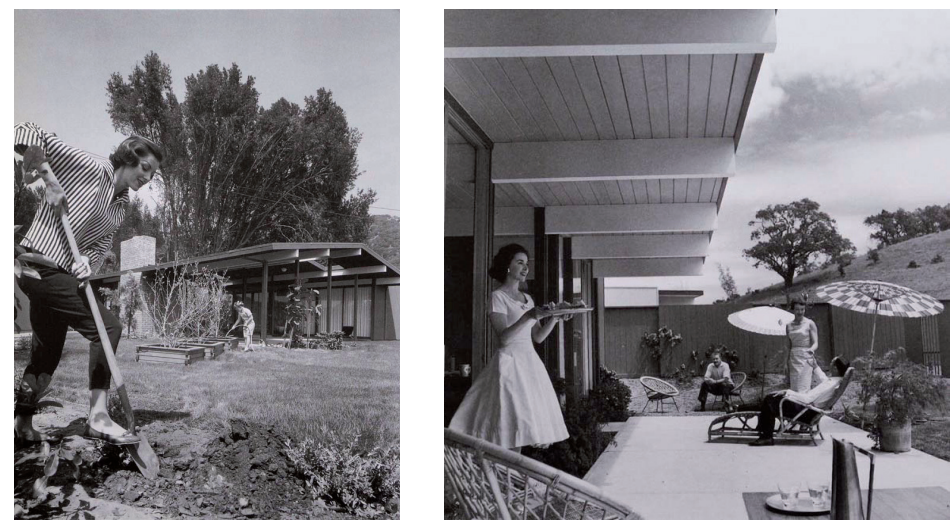

Fig 28. Braun, Ernie: Garden. Fig 29. Braun, Ernie: Celebration. Fig 30. Braun, Ernie: Mother and Child. 1960.

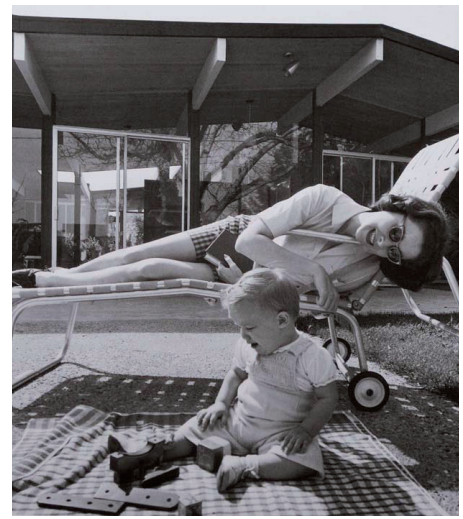

extend domestic life outdoors, also applying this exterior spatial criteria to the interior, and by enabling a domesticity of the enjoyment of everyday life whose main banner is the woman, the person who keeps everything in order and under control from her strategic cockpit, the kitchen. The flexibility of the open-plan, the use of the outdoors as a domestic space and the inclusion of the kitchen in the living house life were distributional criteria with the ability to determine life in the house. The domestic project is not only a reflection of a given lifestyle, neither a cultural product far from cultural production. It is the laboratory in which to foster new day-to-day dynamics that redefine the everyday lifestyle.

The Case Study Houses program is an antecedent of this confidence in the architecture's ability to promote new living and building ways. Quincy Jones and Frederick Emmons actually participated in it, with model 24. It was a project in which the care for daily life criteria and use -e.g. acoustic or visual privacy- defined the formalization of a set of houses half-buried in the ground in an undulating prairie. These homes are designed for life to take place in them, as the ones Joseph Eichler promoted. However, Eichler was able to make a market value out of the lifestyle his houses offered. Eichler saw that the greatest luxury he could offer his potential customers at that time was the lifestyle his homes provided. Eichler believed in the capacity of architecture to promote a higher quality of life, and so it was expressed in his principal motto: "Eichler Homes: designed for better living". (11) (Fig. 31) 
El programa Case Study Houses es un antecedente de esta confianza en la capacidad de la arquitectura de propiciar nuevas formas de construir y de vivir. Quincy Jones y Frederick Emmons participaron de hecho en él, con el modelo 24 , un proyecto en el que la atención a criterios de vida diaria y uso, como privacidad acústica o visual, determinan la formalización del conjunto en una pradera ondulada en la que se semientierran las distintas casas. Estas casas están pensadas para la vida en ella, como las que promocionó Joseph Eichler. Pero Eichler supo hacer de la vida que sus casas ofrecían un valor de venta, ofreciendo cierta sensación de lujo inesperada en el mercado de la vivienda asequible. Eichler vio que el mayor lujo que podía ofrecer en esos momentos a sus potenciales clientes era la forma de vida que sus casas propiciaban. Eichler creía en la capacidad de la arquitectura para propiciar una mayor calidad de vida, y así lo expresaba en su principal eslogan: "Eichler Homes: designed for better living". (11) (Fig. 31)

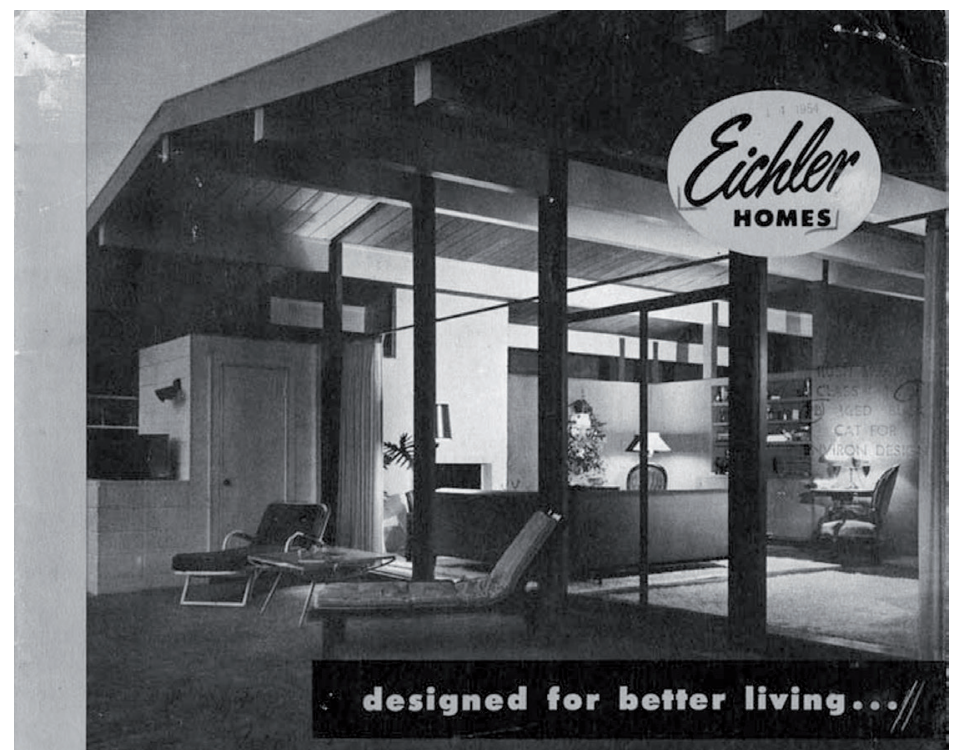

Fig 31. Eichler Homes: Brochure. 1952.

\section{NOTAS}

1. BANHAM, Reyner. 'Cuatro artículos sobre Los Angeles'. Lo ordinario. Barcelona: Gustavo Gili, 2010.33 p.

2. EICHLER, Joseph. 'Eichler Homes X-100, an experimental research house' X-100 opening brochure 1956. http://totheweb. com/eichler/brochures/X-100/index.html, fecha de consulta: ocubre 2013.

3. ADAMSON, Paul; ARBUNICH, Marty. Eichler. Modernism Rebuilds the American Dream. Utah: Gibbs Simth, 2002. 174 p. 4. STERN, Lanning; DITTO, Jerry. Design for living. Eichler Homes. San Francisco: Chronicle books, 1995. 87 p. 5. MCWILLIAMS, Carey. Southern California, an Island on the Land. Utah: Gibbs Simth, 2010.96 p. [1 $1^{\mathrm{a} e d .: ~ 1947] ~}$

6. EICHLER, J. Opus cit.

7. Ibídem.

8. ADAMSON, P.; et al. Opus cit. 78 p.

9. Ibídem. $168 \mathrm{p}$.

10. Ibídem. $168 \mathrm{p}$.

11. Ibídem. 154 p.

\section{NOTES}

1. BANHAM, Reyner. 'Cuatro artículos sobre Los Angeles'. Lo ordinario. Barcelona: Gustavo Gili, 2010.33 p.

2. EICHLER, Joseph. 'Eichler Homes X-100, an experimental research house'. X-100 opening brochure 1956. http://totheweb. com/eichler/brochures/X-100/index.html, fecha de consulta: ocubre 2013.

3. ADAMSON, Paul; ARBUNICH, Marty. Eichler. Modernism Rebuilds the American Dream. Utah: Gibbs Simth, 2002. 174 p. 4. STERN, Lanning; DITTO, Jerry. Design for living. Eichler Homes. San Francisco: Chronicle books, 1995. 87 p.

5. MCWILLIAMS, Carey. Southern California, an Island on the Land. Utah: Gibbs Simth, 2010.96 p. [1 ${ }^{\mathrm{a} e d .: ~ 1947] ~}$

6. EICHLER, J. Opus cit.

7. Ibídem.

8. ADAMSON, P.; et al. Opus cit. 78 p.

9. Ibídem. $168 \mathrm{p}$.

10. Ibídem. $168 \mathrm{p}$.

11. Ibídem. $154 \mathrm{p}$. 